\title{
Islam and Image-Making: Effects of Learning Visual Art on the Muslim Child in Tamale
}

\author{
Mohammed M. Hussein ${ }^{1^{*}} \quad$ Peligah, Y. Seidu [Alhaji Prof.] ${ }^{2}$ \\ 1.Department of Vocational Skills, Tamale College of Education, P. O Box 1 ER, Tamale, Ghana; MPhil. Arts \\ and Culture, University of Education, Winneba, Ghana. Bed. Basic Education \\ 2. Faculty of Creative Arts and Technology, Kumasi Technical University, Kumasi, Ghana. He was the Dean, \\ Faculty of Creative Arts and Technology, Kumasi Technical University, Ghana;(2012- 2016). He was Rector of \\ the Tamale Polytechnic 2006-2012, and Former Head of the Department of Art Education, Kwame Nkrumah \\ University of Science and Technology. Ghana. 2003-2005. \\ * E-mail of the corresponding author: husseinmansuru@yahoo.com/husseinmansuru@gmail.com.
}

\section{Abstract}

The idea of prohibition of Image-Making in Islam has become a source of worry to the Muslim Ummah worldwide and Tamale is no exception. The term Ummah refers to the Community of Muslims, used both for local and wider groups at national and international levels. In this paper it refers to the Ummah of the Tamale Metropolitan area. The premise of this study stems from the researcher's personal experience and observation where Muslim children are influenced to avoid expressing their artistic skills and talents especially in the ImageMaking aspect of Arts and Culture. Thus, the researcher sought to dig into the reasons that account for this by looking at the existing views from the Quran, the Hadith, Islamic Scholars, Islamic education and the history of Islamic Arts and Culture. The study mainly used questionnaires, interview and observation in eliciting the data regarding the views of Islamic Scholars, Teachers, and Students based on the existing views from the Quran and Hadith. Out of hundred and forty-two (142) respondents for the questionnaires, hundred (100) were Students, twenty were Teachers (20) and twenty-two (22) were Islamic Scholars. Form the twenty-two Scholars who answered the Questionnaire, eleven (11) were interviewed and their environments were observed. Data from the questionnaire were analysed using the Statistical Package for Social Science (SPSS) version 20 and Excel. The data collected helped the researcher to map out the patterns among conceptions and perceptions of the Muslim Ummah in Tamale regarding the said prohibition of Image-Making in Islam. The cross-sectional survey design was employed in the collection and analysis stages. Tamale Metropolis has no single structured Islamic Administration presiding over issues regarding the Ummah. The data suggest that the Ummah is divided into three sections, each holding a different view and position regarding the prohibition of Image-Making. The study also shows the weaknesses of Islamic Scholars, in their varying interpretations of the Quran and Hadith, regarding issues of Culture and Arts among the Ummah. The study reveals that none of the Islamic Senior High Schools within the Tamale Metropolis offers Visual Art programmes. Only three other secondary schools in Tamale offered Visual Art in their curricular. It also revealed that most Muslim Students gave up Visual arts for other courses due to the gravity of fear Islamic Scholars instilled in them concerning the divine punishment for violating the said prohibition of Image-Making. There are a few Muslim Artists, Students and Teachers of the Image-Making related disciplines in Tamale and even beyond, and it is therefore important for the stakeholders of Art and Culture in the Educational and Training Institutions in Ghana to constructively engage with, and encourage the Muslim Ummah to develop these aspects of Knowledge and skill among their children and adherents for holistic individual and collective developments.

Keywords: Islam, Image-making, Ummah, Quran, Hadith, Visual Arts

DOI: $10.7176 / \mathrm{JPCR} / 47-03$

Publication date: December $31^{\text {st }} 2019$

\section{Introduction}

The inhabitants of the Tamale Metropolis are mostly Muslims since this was the first religion exposed to them by traders from North Africa and other West African communities. Therefore, not surprising, almost $90 \%$ of the ethnic majority Dagombas are Muslims. Christianity, on the other hand, arrived later from the South and hence is mostly practised by non-Dagomba ethnic groups. Ayuba (2011) observed that Islam already existed in Ghana among the Gonja as far back the middle $16^{\text {th }}$ century, among the Dagombas by the $17^{\text {th }}$ century and among the Asante by the $18^{\text {th }}$ century.

As regards this study, the term Image-Making refers to the Art of creating an image, that's either by painting, sculpture (modelling and curving), engraving, embroidering and printing especially of any animate form. In some cases, Image-Making is used interchangeably with Art. Based on the above description of ImageMaking and Art, the study focused on Paintings, Sculptures, Photography and Video and their position in Islam, that is whether they are permissible (halal) or forbidden (haram).

On the bases of this study, art can be defined as one of the most useful and fascinating divisions of human knowledge in the name of education. As an inherent skill, art forms the bases of civilisation and the development 
of every culture and tradition, and has often been the record and standard of the development of past communities used by archaeologists. The essential skill in art is creativity, careful analysis, clear reasoning and experimentation which help us to create, invent and innovate our ideas. The effects of the Artistic skills run across all human endeavours from the production of goods to the provision of services.

Thus, the core study of art at the basic level of education in all developed and developing countries is necessary for the holistic development of the child. The artistic development of the child is intertwined with his general cognitive and psychological development. The normal sequence of development in child art has been observed, collected, described, and categorized since the nineteenth century by specialists in child development, educational psychology, and art education; work has focused, probably for practical reasons, on graphic expression, painting and clay-modelling (Rubin 2005). Artistic expressions in general help in the complete growth and development of the child. When this is missing during child development, it can affect both the physical and psychological development of the child.

The multiple misconceptions on the position of Islam on some genres of Art (Image-Making particularly) have been a source of worry to many Muslim art students', Teachers, educationist and psychologist worldwide. This has raised several questions among scholars of this related area In the Tamale metropolis, most Muslim children who are gifted in the genre of Image making are denied the privilege to explore within their gifted field due to several factors which include the literacy rate, availability of artistic materials for children to explore, teachers and parents' attitudes and most significantly the diverse and often confusing 'Islamic' views in art. Children with this precious gift need to be groomed in an art intensive atmosphere in order to realise the potentials of their gifts.

The notion that Art is an affront to the Divine creation has engulfed many Muslims globally including those in Ghana and for that matter Tamale. In recent years, there have been several advances towards the realities of the position of Islam on this issue. Majority of scholars who raise concerns on this issue are the elite Muslim or northern Ghanaian scholars who have largely researched into, and are exposed to the global array of discourse on the subject. Peligah in the Department of Art Education of KNUST in the early 1920s and some his students; amongst whom was Ms Amina Gombilla who wrote her M.A. Art Education Thesis on the subject. (See details under acknowledgements).

\section{Methodology}

A descriptive cross-sectional survey study was employed to collect information from a sample drawn from a predetermined population (Clarke, 2005). This was due to the fact that the study examined the value of ImageMaking among the Muslim folks in Tamale. It was used to describe and analyse the factors that affect the Muslim student's decisions for studying Art courses, or not, especially those involving Image-Making.

The population of the study was obtained from ten selected public schools and some selected Islamic scholars in the Metropolis.

Samples for this study were drawn from the three main Islamic denominations in Tamale, as regards their various schools of thought, for both the Scholars and Ordinary Muslims. Those denominations were Sunni, Shi'a and Ahmadiyya Islamic groups. In Tamale, the Sunni denomination is further divided into two sects, which are the Ahlul-Sunna Wal-jamaa'ah and the Tijaaniyya Sufi brotherhood. Other samples were taken from the ten selected schools for the study. Respondents were chosen by the means of both stratified and purposive sampling procedures. The total sample size from the ten schools and the scholars selected for this study was 142 .

The sampling was stratified using the probability sampling technique for the selection of twenty-two (22) scholars from the three (3) main Islamic denominations in Tamale. The criteria for the sample size allocation for each group were that, every third person of the group (strata) was interviewed. The breakdown is as follows, six (6) scholars from the Ahlul-Sunna-Wal-jamaa'ah section, and ten (10) from the Failla or Tijaaniyya section of the Sunni denomination, two (2) from the Ahmadiyya and finally four (4) from the Shi'a respectively.

In the case of the schools, a purposive sampling technique was adopted to select four (4) Senior High Schools (S.H.Ss) out of the ten (10), S.H.S in Tamale. Unfortunately, since none of the Islamic S.H.S pursues visual Art programmes; therefore, all the four schools sampled were Public Senior High Schools. Another five (5) Islamic Junior High Schools(J.H.S.s) were selected out of the one-hundred and twelve (112) J.H.S consisting of three Islamic (3) J.H.Ss and two (2) Public Junior High Schools. The most significant feature of the sample was that the only Polytechnic within the Region that is Tamale Polytechnic was included. Art teachers were also sampled based on the schools involved.

The study focused on four main instruments, which were documents and documentation, interview, questionnaire and observation. These were employed as tools for seeking information from the selected population. The English and Arabic translation of the Qur'an and Hadith (Sahih Bukhari and Sahih Muslim collections) were also considered.

Three types of questionnaires were designed and administered to the Students and Teachers of Art, and some Islamic Elite Scholars. The questionnaires used both open and closed ended questions. Questions for the 
Islamic scholars centred on the issue of the prohibition of Image-Making in Islam. Those for the teachers of Art were on how this issue affects the enrolment and the learning of Muslim children in the Art programs. For the Students of Art, the questions were based on the challenges they face as practicing Muslims learning Arts.

Interview adopted for the study was semi-structured type. This was the most significant data collection instrument as it gave the researcher the opportunity to facilitate non-threatening guided conversations through the use of topic-specific questions, which were open-ended. This was to enable the interviewees to decide how they will answer the questions (Yin, 2009; and Babbie, 2007). It was administered to the various scholars and some ordinary Muslims of the three different Islamic denominations in Tamale. The purpose was to assess and analyse their views and positions on the issue of the prohibition of Image-Making in Islam.

The interviews were audio recorded in order to preserve the information and to keep track of the dates and details of the data. Observation was employed in the study to enable the researcher gather further information about the subject to provide authentic data during the interview and questionnaire session. Adopting the nonparticipatory observation technique, the researcher paid intense attention to the environments of the respondents in order to identify any Art works or figural representation. Figural representations on walls were the main target of observation. This helped the researcher to guess the position or the view of the respondents even before the beginning or the end of the interview.

\section{Data Analysis}

Questionnaires were edited and cleaned to ensure consistency, sufficiency and relevance. It was coded for analysis. The software employed for the analysis was the Statistical Package for Social Science (SPSS) version 20 and Excel. Charts, Tables, frequency distributions, percentages and means were used for the analysis. Interviews recorded were played back for transcription and the recording of data. Information obtained from these interviews were further presented, analysed and discussed under the discussion of findings. As the researcher is a practicing Muslim, his observation and discussions on the issues under study were based on seizing the slightest opportunity given him, to interact with all the stake holders especially the Scholars of Islam and Art.

Table 1: Population of Selected Schools and Islamic Scholars with their Sample Sizes.

\begin{tabular}{lcc}
\hline Names of S. H. S / Polytechnic & Population Size & Sample Size \\
\hline Tamale Senior High & 157 & 13 \\
Kalpohin Senior High & 180 & 11 \\
Vitting Senior High & 240 & 13 \\
Pon-Tamale Senior High & 295 & 12 \\
Tamale Polytechnic & 300 & 17 \\
Total & $\mathbf{1 , 1 7 2}$ & $\mathbf{6 6}$ \\
\hline
\end{tabular}

Source: Based on field Survey

Table 1.1: The table below shows the breakdown of the J.H.S sample.

\begin{tabular}{lcc}
\hline Names of Junior High Schools & Population Size & Sampling Size \\
\hline Abubakar Sadiq Junior High & 250 & 10 \\
Zogbeli Junior High & 348 & 11 \\
Fatuhul-Mubeen Junior High & 146 & 11 \\
Manhalia Junior High School & 558 & 12 \\
Police Barracks Junior High & 400 & 10 \\
Total & $\mathbf{1 , 7 0 2}$ & $\mathbf{5 4}$ \\
\hline
\end{tabular}

Source: Based on field Survey

Table 1.2: The table below shows the breakdown of the Islamic Denomination.

\begin{tabular}{lcc}
\hline Scholars Based on Denomination & Population Size & Sample Size \\
\hline Ahli Sunna Wal -Jammah & 30 & 6 \\
Tijaniyya & 25 & 10 \\
Ahamadiya & 10 & 2 \\
Shia & 15 & 4 \\
Total & $\mathbf{8 0}$ & $\mathbf{2 2}$ \\
\hline Source: Based
\end{tabular}

Source: Based on field Survey

\section{Presentation and Discussion of Findings}

Based on the reviewed literature, the interviews and the study questionnaires, discussion of findings are made under the following sub-headings. 
- $\quad$ The conceptions of Muslims about the Art of Image-Making.

- $\quad$ Views from the Quran and Hadith on Image-Making.

- The differences in views of the Islamic Scholars on Image-Making.

- $\quad$ The bases for the prohibition of Image-Making in Islam.

- $\quad$ Effects of the prohibition on the Muslim child learning Art.

4.1 The Conceptions of Muslim about the Art of Image-Making

There are denominations in Islam, and the issue of the prohibition of image-making is also perceived differently among them. This prohibition has been discussed and argued by every school of thought in Islamic jurisprudence. Certainly, the hadith stated for short that; "accursed be the picture-maker" and this affects all kinds of picture-making including photography (Awal, personal communication, 11 January, 2014). This gives the impression that photography is also prohibited in Islam. Other ahadith state that; "whoever makes a picture, on the day of judgement Allah will ask him to give life to it, and he will not be able to do so". The Arabic terms used in these hadith were "Soorat" "Tasaaweer" "Tasaaleeb", which means picture, figure or image and " $\mathrm{Al}$ Musawwiroon" meaning the Picture-Makers, and this generalises all kinds of picture-making (Usmani, 2010).

Ibn Baaz (1997), opined that Picture-Making of which photography is one of the methods is prohibited in Islam. He added that the Sharia does not allow this idolatrous and evil practice, and that all methods of picture production are condemned equally under the Islamic ban. This therefore suggest that all method of PictureMaking falls within the category of great sins.

In an interview with Awal; Ilyass; Al-Hussein; Salawatiya and Al-Hassan on (December, 2013), they all commented that, in analysing these hadith, one needs to consider the background of the narration and the time of the narration. The condition on which the narration was made will give you a better understanding of the hadith. The kind of images that were found at that time will give you a comprehensive idea or the message of the hadith. Though the prohibition generalises all pictures but, in some hadith, statues are specifically mentioned (Awal, personal communication, 11 January 2014).

Sheikh Bawa in an interview on 19 October, 2013 stated that the Ulamah of the Sunni School of thought have been grouped into two; the first group maintains that, all images of animate objects are prohibited. The second group are of the view that apart from statues, any animate object which cannot cast shadow by itself is permissible. Based on this, some scholars said that the prohibition was limited to sculpture pieces. In an interview on 7th March 2014, Professor Abdul Razak Tahir stated that most Scholars are of the view that sculptors try to imitate the handy work of Allah. That Allah created man and men try to create something that resembles man and this can only be related to statues. Pictures don't look like the real image of man but the reflection of man. Pictures have no reality, they can be torn away, but for statues, they look too real.

They all based their evidence on the hadiths of the prophet (S.A.W) that condemn pictures and all acts of image-making. For example, one hadith in Bukhari narrated by Ibn Abbaas states that; "Whosoever makes a picture will be punished and be forced to give life to the picture, and he will not be able to do so." Thus, the first group based on this hadith and the like eliminated all kinds of images of animate objects from picture state to statues. The second group on the other hand maintained that, the prohibition is only on the statues and the 3Dimensional, [3-D] images and not the 2-Dimensional [2-D] images. All those who maintain the prohibition on all kinds of images do not even take photographs unless under a pressing condition or need. The following tables present the general views of the respondents on the prohibited and permissible Art works in Islam.

Table 2: Views of the respondents on the prohibited types of Art works in Islam.

\begin{tabular}{lccc}
\hline \multicolumn{4}{c}{ Designation } \\
\hline Prohibited Art & SCHOLARS: $\mathbf{n = 2 2}$ & TEACHERS: $\mathbf{n = 2 0}$ & STUDENTS: $\mathbf{n = 1 0 0}$ \\
\hline Sculpture and Nude Art & $50 \%$ & $35 \%$ & $36 \%$ \\
Nude Art or Pictures & $20 \%$ & $65 \%$ & $40 \%$ \\
Sculpture Only & $18 \%$ & $0 \%$ & $18 \%$ \\
Images for Worship & $12 \%$ & $0 \%$ & $6 \%$ \\
\hline
\end{tabular}

Source: field survey, January 2014

Table 2.1: Views of the respondents on the permissible types of Art works in Islam

\begin{tabular}{lccc}
\hline & \multicolumn{3}{c}{ Designation } \\
\hline Permissible Art & SCHOLARS: $\mathbf{n = 2 2}$ & TEACHERS: $\mathbf{n = 2 0}$ & STUDENTS: $\mathbf{n = 1 0 0}$ \\
\hline Calligraphy & $45 \%$ & $50 \%$ & $77 \%$ \\
Photography & $27 \%$ & $35 \%$ & $6 \%$ \\
Sculpture & $9 \%$ & $15 \%$ & $4 \%$ \\
Painting & $18 \%$ & $0 \%$ & $10 \%$ \\
Leather Work & $0 \%$ & $0 \%$ & $4 \%$ \\
\hline
\end{tabular}

Source: Survey, January 2014 
In an interview on 6 January 2014, Dr. Al-Hussein commented that Paintings, drawings and statues of human beings or animals were all called 'Soorah, 'which means pictures, without any specification at the time of the existence of the Prophet (S.A.W). Therefore, whether, pictures, drawings, paintings or statues, they are the same in a way that they all portray the images of human or animals. In another interview on 11 January 2014, Dr Mohammed Awal stated that Soorah or picture in Islam can be looked at in two dimensions, either a statue or a picture. In the case of the statue, animate objects are curved out of wood or modelled out of the earth. The product may be a human-image, an animal-image, the image of an angel or a spirit. If the statue is any of the above, then it is haram in Islam. Some scholars specified the prohibition on human, jinn, angels and spirits but rather excluded animals, trees and non-living things, even though the proof or the hadith generalised it.

On the 6 January 2014, Dr. Tamim Stated in an interview that Imam Nawawi the translator of Sahih Muslim stated in his translation that all the Ulamaa had agreed that sculpture and statues are prohibited. But for painting, minority of the Ulamaa have agreed that it is permissible, while the majority still maintained that it is prohibited. The two groups all base their argument on the series of hadith that bear this prohibition.

\subsection{The view of the Quran and Hadith on Image-Making The Quran}

(1) In Suratul Al-Araf: 148 Allah said; "The people of (Prophet) Musa (A.S) made in his absence, out of their ornaments, the image of calf, (for worship): it seemed to low: did they not see that it could neither speak to them, nor show them the way? They took it for worship and they did wrong" (Maulana, 2002).

(2) In Suratul Al-Anbiya: 51-54, Allah said "And certainly We gave to Ibrahim his rectitude before, and We knew him fully well. Behold! He (Abraham -A.S) said to his father (the brother of his father whom he used to call father out of affection) and his people, "What are these images, to which you are (so assiduously) devoted?" They said, "We found our fathers worshiping them." He said, "Indeed you have been in manifest error, you and your fathers." (Maulana, 2002).

(3) In Suratul Saba: 13 Allah said; "They worked for him (Prophet Sulaiman -A.S) as he desired, (making) arches, images, basins as large as reservoirs, and (cooking) cauldrons fixed (in their places):"Work O'Sons of David (A.S) with thanks! But few of My servants are grateful!” (Maulana, 2002).

The first Quranic verse informs us about what happened in the absence of Prophet Musa (A.S), when some people made an image of a Calf for worship. The second Quranic verses also tells us about some people in Prophet Ibrahim's (A.S) time made some images and worshiped them. This act on the part those people were wrong according to the Qur'an. The third Quranic verse informs us of the work of the Jinn as per the orders of Prophet Sulaiman (A.S) in which images were part of what they made for him. This act on their part was right, because these images were not meant for worship.

The above Quranic verses confirm the fact that the intention behind making images has to be virtuous. Images made with bad intention (for worship) are disallowed and images made out of good intention are allowed in Islam. This was a fact supported and confirmed by most Islamic scholars during the interview. It was made clear that there is no clear-cut verse from the Quran that vividly state the prohibition of image-making in Islam, but rather the Hadith stated that.

The review of literature indicated several verses from the Quran that seem to express the visual appreciation of image-making. Even though the hadith seemed contrary to this, there are also verses from the Quran that spoke positively about statues for decoration and statues for education as found in the story of prophet Solomon (A.S) and Jesus (A.S) [34:12-13 and 3:48-49]. Most scholars confirm this fact from the Quran, which implies that even if the hadith prohibit the art of image-making then it is for the displacement of idolatry. Therefore, most scholars concluded that, image-making can be permissible for any reason that will lead to the positive progress and development of mankind, but not for worship or for the fulfilment of any negative intension.

\subsection{The Hadith}

In spite of dozens of ahadith against the making of images, there were still few which allowed Images made with good intention, but essentially not for worship. The following are some hadith collections indicating exceptions for the prohibition.

(1) In a hadith narrated by Busr bin Said (RTA): That Zaid bin Khalid Al-Juhani (RTA) narrated to him something in the presence of Said bin 'Ubaidullah Al-Khaulani (RTA) who was brought up in the house of Ummul Momineen Maimuna (RTA). Zaid (RTA) narrated to them that Abu Talha (RTA) said that the Prophet (SAW) said, "The Angels (of Mercy) do not enter a house wherein there is a picture." Busr (RTA) said, "Later on Zaid bin Khalid (RTA) fell ill and we called on him. To our surprise we saw a curtain decorated with pictures in his house. I said to Ubaidullah Al-Khaulani (RTA), "Didn't he (i.e. Zaid-RTA) tell us about the (prohibition of) pictures?" He said, "But he exempted the embroidery on garments. Didn't you hear him?" I said, "No." He said, "Yes, he did." (Bukhari - Book no: 54, Hadith no: 449; Translated by Khan 1997).

(2) In a hadith narrated by Aisha (RTA) - "I used to play with dolls in the presence of the Prophet (SAW) and 
my girlfriends also used to play with me. When Allah's Apostle (SAW) used to enter (my dwelling place) they used to hide themselves, but the Prophet (SAW) would call them to join and play with me. (Bukhari; Translated by Khan 1997).

(3) In another hadith narrated by Aisha (RTA) "When the Apostle of Allah (SAW) arrived after the expedition of Tabuk or Khaybar (the narrator is doubtful), the drought raised an end of a curtain which was hung in front of her store-room, revealing some dolls which belonged to her. He asked: What is this? She replied: My dolls. Among them he saw a horse with wings made of rags, and asked: What is this I see among them? She replied: A horse. He asked: What is this that it has on it? She replied: Two wings. He asked: A horse with two wings? She replied: Have you not heard that Solomon had horses with wings? She said: Thereupon the Apostle of Allah (SAW) laughed so heartily that I could see his molar teeth. (Abu Dawud, cited in Peligah, 2003).

From above Ahadith, it can be concluded that; Pictures drawn, taken or even making shapes of human beings or animals is allowed in Islam provided they are made for some good purpose; even as playing things[toys] for children. Table 4.7 presents the comparative analysis of the sources of the prohibition of ImageMaking by the designated respondents.

Table 3: Comparative analysis of the Sources of the Prohibition of Image-Making.

\begin{tabular}{|c|c|c|c|}
\hline \multirow[b]{2}{*}{ Prohibition Source } & \multicolumn{3}{|l|}{ Designation } \\
\hline & SCHOLARS $n=22$ & TEACHERS $\mathrm{n}=\mathbf{2 0}$ & STUDENTS $\mathrm{n}=100$ \\
\hline Hadiths & $100.00 \%$ & $75.00 \%$ & $25.00 \%$ \\
\hline Quran & $0.00 \%$ & $15.00 \%$ & $22.00 \%$ \\
\hline Don't Know & $0.00 \%$ & $10.00 \%$ & $35.00 \%$ \\
\hline Non-response & $0.00 \%$ & $0.00 \%$ & $20.00 \%$ \\
\hline
\end{tabular}

Source: Survey, January 2014

The above table shows the comparative analysis of the sources of the prohibition of image-making according to the three main categories designated to respond to the questionnaire. These categories were made of the Scholars, the Teachers of Art and finally the Students of Art, with their respective frequency of 22,20 and 100. From the table, all the Islamic scholars representing $100 \%$ unanimously agreed that the Hadith was the main source of this prohibition. $75 \%$ of the teachers share the same view with the scholars, while $15 \%$ of the teachers indicated that the source of this prohibition was mainly the Quran, with $10 \%$ of them indicating that they have no idea as regard the source of the prohibition. For the students, $35 \%$ of them indicated that they have no idea as regard the source of the prohibition, where as $25 \%$ of them share the same view with the scholars and finally $22 \%$ of the students identified the Quran as the main source of the prohibition of image-making. This suggests that the real source of the prohibition is indeed the Hadith as all the Islamic scholars indicated.

\subsection{Some Problems with the Hadith Literature}

Imam Hussein Rashid, in an interview, on the 6th of Much 2014 stated that if a hadith conflicts with a verse from the Quran, that hadith is said to be nullified. He added that most Hadith regarding the prohibitions of the possessions of dogs and images in homes conflicts with some verses in Quran chapter 17 (that is, the story of the people of the cave and their dog).

Sheik Mohammed Awal of Zaitun Islamic Institute, America, on the $4^{\text {th }}$ of May 2013 also expressed his reservations for some Hadith literature because they seem not only to conflict with some verses from the Quran, but also or even the $21^{\text {st }}$ century science. For instance, a certain Hadith indicates that the planet earth is created on the back of a fish. This does not agree with Quran [21:30] that talks on the creation of the universe from some gaseous particles which is proved by the $21^{\text {st }}$ century science. Sheik Abdul-Mumin Dalhu on the $12^{\text {th }}$ December 2014 also expresses his reservation on some Hadith in Sahih-Bukhari because it conflicts with some verses of the Quran and even contradicts with each other.

\subsection{Refutation of some Hadith}

The hadith that states that every picture-maker will be cast into hell fire on the day of recompense cannot stand the logic of the Quran and the Sunnah. This is because the same source of Hadith states another Hadith that permits images on garments, children's playing dolls, and even deformed or half-form statues. If indeed the above-mentioned Hadith is true, then the makers of the exempted images will be also cast into hell fire. And if the makers of the permissible images will be cast into hell fire, then why will another Hadith permit their artefacts. These are obvious contradictions of Hadiths that have confused the Muslim Ummah regarding imagemaking.

Imam Hussein Rashid on the 6th of February 2014 commented on the contradictions of hadiths of similar contents, but different chain of collection. He stated that the language maturity and the literature of the Prophet (SAW) were several steps ahead of his companions and only a few of them could remember the exact words and vocabulary used by him after several years before documentation. Even understanding the actual meaning and implication of the sayings of the Prophet (SAW) need a divinely aided brain. He added that, the likeness of the 
Prophet and his Companions in the face of intellectual maturity were as that of the professor and the primary school pupils.

\subsection{The Differences in Views of Islamic Scholars on the Prohibition of Image-Making}

Denominations in Islam came about from the first major crisis that characterised the succession of the prophet after his demise. As result, two major denominations of interpretation sprung up from the hitherto unified Muslim Ummah (community) which is subsequently designated as Sunnism and Shi'ism. With time, the Sunni and Shia themselves were subdivided into a number of smaller communities and sections with a particular theological and legal doctrine that evolved gradually over several centuries. According to Daftary (2012) other communities of interpretation in the form of religio-political movements or schools of thought began to appear among the early Muslims during this formative period.

In modern Ghana, there are mainly about three Islamic denominations, namely, the Sunni, the Shia and the Ahmadiyya. The Sunni being the majority consist of the Ahli Sunna Waljama'a and the Tijaaniyya. These two sections of the Sunni denomination are generally misconstrued as different denominations, though they all emanated from the Sunni denomination. In recent years, the "Ibaadiyya" or "Ahlul Haqq wa Istiqaama" (Istiqaama for short) have also appeared in the Ghanaian Islamic landscape, being mainly active in southern Ghana, which are outside the study area.

The most important aspect of this issue is that the Muslim denominations and sections in Ghana and beyond differ in the interpretation of the Islamic theology, of which those hadith that pronounced the prohibition of image-making are included. The Shias, particularly those in Tamale, do not believe in the series of hadith from Sahih Muslim and Bukhari that spell out the prohibition of image-making. The Shi'ite school is called Ja'fariyya or Immamiyya because they follow the Imams of the Ahlul-Bayt. In principle they take their teachings of Islam from the 12 Imams from the Prophet's household. They accept hadith from all other sources that confirm the teachings of these Imams and the Quran, and do not contradict the Quran. The Ahmadiyya and the Sunni however believe in the hadith collection of Bukhari and Muslim, but they differ in the interpretation of some few hadith from these collections including those on the prohibition of image-making (Faheem Ahmed Khadim, personal communication, 2014). The figure below depicts the denomination of Islamic Scholars in Tamale.

\section{Denomination of the Islamic Scholars}

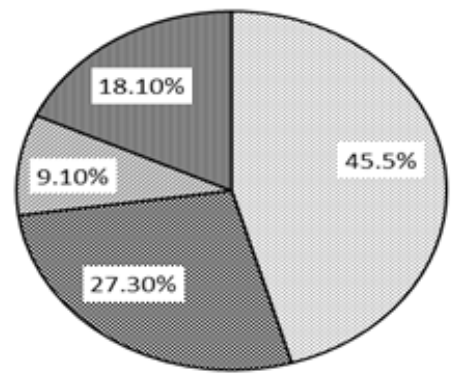

口Tijaaniyyah

ש Ahlu-Sunnah

口Ahamadiyyah

$\square$ Ahlul-Bayt (Shi'a)

Figure 1: Denomination of the Islamic Scholars.

Table 3.1: A Cross tabulation of the perceptions of Scholars based on their denomination.

Is this prohibition a true teaching of Islam?

\begin{tabular}{llll}
\hline Denomination & Yes & \multicolumn{1}{c}{ No } & \multicolumn{1}{c}{ Total } \\
\hline Ahli-Sunna & $6(27.3 \%)$ & $0(0.0 \%)$ & $6(27.3 \%)$ \\
Tijaaniyya & $7(31.8 \%)$ & $3(13.6 \%)$ & $10(45.5 \%)$ \\
Ahmadiyya & $2(9.1 \%)$ & $0(0.0 \%)$ & $2(9.1 \%)$ \\
Ahlul-Bayt (Shi'a) & $0(0.0 \%)$ & $4(18.2 \%)$ & $4(18.2 \%)$ \\
\hline Total & $\mathbf{1 5 ( 6 8 . 2 \% )}$ & $\mathbf{7 ( 3 1 . 8 \% )}$ & $\mathbf{2 2 ( 1 0 0 . 0 \% )}$ \\
\hline
\end{tabular}

Source: Survey, January 2014

4.7 The Bases for the prohibition of Image-Making in Islam According to Scholars

Sheikh Ilyasu on 23 December, 2013, indicated in an interview that; Islam as the way of life and a religion of peace has the way it looks at issues. There are issues that the prophet (S.A.W) will totally condemn, and those that sometimes are given reasons for why they are condemned. In some cases, it is a temporary reason, and when 
that reason is over, and then you can now go back to what was prohibited. At certain times the prophet (S.W.A) himself lifted the ban; But in some cases, where no clear directive was given by him, the Islamic theologians under some consensus will have to use their own juristic reasoning to decide on issues of relevance. So, it is therefore based on certain circumstances that some prohibitions were made. He concluded that the position of Islam against these Images is because some people have worshiped such images in the past.

Dr Tamim on 6 January, 2013, in an interview said; "the prohibition of image-making in Islam was basically for the following reasons; the first reason was that image-making serve as bases for idolatry, and secondly, the image-maker in this sense tries to imitate Allah." Al-Hassan on 19 December, 2013, in an interview also stated that the primary intention for the prohibition on images was to stop the worshiping of statues as idols. This is because during the jahilia period (that is the period of ignorance) the people of Mecca were worshiping about three-hundred and fifty (350) idols which were housed inside the Kaaba as their smaller gods.

From the Ahlul-Bayt point of view, Sheikh Abdul-Mumin Dalhu in an interview on 12 January 2013 said; "The prohibition is not on the art itself, there is nothing wrong with that kind of Art or science. The prohibition is when you take the statue or image and you now use it as a source of worship, you worship it as an idol that is what is prohibited, but not the art of picture-making." The message of the Ahlul-Bayt is very clear here, that the product when worshipped is forbidden in Islam, but as an art or science, there is nothing wrong with that.

If one worshiped any image, it means the image has been considered a kind of god and that is forbidden. But if there is an image, either a picture or statue, that is not intended for worship, then there should be nothing wrong about it from the logic of 'Sharia' or the law. He added that, from the logic of sharia, the idea is not to use these images as objects of worship, once you are not using them for that; there should be no argument about having those images (Al-Hussein, personal communication, 6 January, 2014).

Al-Hussein concluded that it is therefore the intension behind the painting and statues of these human beings that are in question. Thus, the Islamic perspective of condemning the pictures and statues is when they are intended for spiritual purposes, either worshiping or believing that the picture of that individual has some spiritual impact. These are the considerations of the prohibition, but when they are not intended for either of these then there is nothing wrong with that.

Consequently, the primary reason for the prohibition of picture-making at that time was solely of preventing idolatry which Prophet Mohamed (S.A.W) was fervently against. The main factor that accounted for the prohibition of these images was to end the production and worshiping of idols. The table below presents Scholars' views on the bases for the said prohibition

Table 3.2: The reason for the Prohibition According to Islamic Scholars.

\begin{tabular}{lcc}
\hline Reason for Prohibition & Frequency & Percent \\
\hline Worship & 15 & $68.0 \%$ \\
Others not specified & 0 & $0.0 \%$ \\
Non-response & 7 & $32.0 \%$ \\
\hline Total & $\mathbf{2 2}$ & $\mathbf{1 0 0 \%}$ \\
\hline
\end{tabular}

Source: Survey, January 2014

4.8 The prohibition on modern photography, videos and television transmission

It is an old argument between scholars of Islam that pictures or photographs are part of this prohibition or are excluded (Awal, personal communication, 11 January, 2014). Videos and Television transmission were also discussed by the contemporary scholars of Islam. Whilst most scholars from the Sunni denomination still maintain their position on prohibiting all images which affects modern technology, others from the same sect consider this development to be exempted from the prohibition.

At the time of this prohibition, paintings were limited in existence, not to talk of photography and videos which are a recent invention and were totally non-existent. It would therefore have been impossible for the prophet to prohibit this or warn his people against something they did not know (Awal, personal communication 11 January, 2014). This view attracted a scholarly comment by Peligah, That, the question of the prophet's prediction of events to happen even by the end of the world indicates that the prophecies were not limited to things which were known by the companions. He spoke of things that were to come in future which they did not know of as well. Awal (2014) concluded that videos are not in any way like the real creation of Allah because we cannot have the physical feeling of the images seen on videos, but for statues we can feel them. Videos are just the recording of events for replay.

Photography is a recent development and the modern Ulamah have discussed the ruling of its prohibition and permissibility. In their discussions on the ruling of photographs, they based their ruling on two reasons; the first reason was that a picture might in the end be turned into a deity of worship which is 'Shirk' that is associating partner with Allah. The second reason was that the picture-maker or the photographer may be proud 
of being able to create what Allah has created (Tamim, personal communication, December 6, 2013). He added that some Ulamah consider photography as an aspect of Man's own creativity and said that the photographer has not created that image, but rather copied or recorded the reflection of that object onto a medium. Thus, the creature of Allah is copied and recorded by the photographer that is all. Based on this they also concluded that photography is permissible. He concluded that photography is only permissible where necessity demands, and not for fun or for decorative reasons.

The prohibition affects pictures where there is an evil base for the production of the picture. For instance, pictures for worship and for the expression of sexual indiscipline as in pornographic films, magazines and the like are prohibited in Islam. But those used in passports, Identity cards, and driving licences and for security reasons and the like are permitted in Islam (Ilyasu, personal communication, December 2014).

Ironically, a hadith from Bukhari and Muslim states that; "angels do not enter rooms or homes where there are pictures and dogs". This hadith had several interpretations from the various denominations in Tamale. Dr Awal on the 11 January 2014 said in an interview "this hadith is taking a scaring trend and not the reality, this is because even in the non-believer's room angels go to record what they do irrespective of what they keep either pictures or dogs."

Sheik Iliyasu on 23 December 2013 in an interview declared his position as a Sufi as regards this hadith. He declared, "My analysis to this hadith as a Sufi is that, the heart is a home, and the Angels are the light of God. This implies that, the light of God does not settle in the heart that possesses other beings than Allah. Therefore, your heart becomes a home that can accommodate Allah (S.W.T), or a room that can contain the light of God; Angels are the light of God. Even the divine powers are all interpreted to be associated with God. And God doesn't settle in a person heart when that heart is occupied with other unclean issues. He supported his argument with another hadith that states that; "the world looks small no matter its size to contain me God, but the heart of my servant is so wide to accommodate me". He added that having hatred for people is allied to a dog and worshiping other deity is allied to a statue; something 'Shirk' which God doesn't like. He concluded that if your heart harbours any of this, then you won't find God inside you. So, the light of God doesn't settle in the heart that accommodates evil.

Indeed, we carry money, identity cards, traveling passports and others things which contain images on them into the Mosques and the Masjidu Haram. Even in the haram today, photography is allowed, and there are security cameras, TV camera and even satellites to telecast and transmit the ritual activities of Islam across the entire globe. Yet we believe there are angels of mercy with us in the Mosques and the Haram and this seem not to be an act of idolatry to us.

Even if this prohibition is real of Islam, then it does not include photography since photography has become a necessity to humanity. And Islam is not a curse for humankind. Certainly, Allah knows very well that time will come when one-third of human activities will rely on pictures. Otherwise if the prohibition is indeed general as indicated by most hadith, then it will be appropriate to conclude that the prohibition must be based on the intention behind the production of that image be it a statue or a picture since there is a hadith that states "actions are judged by the intension", and this is position shared by most Islamic scholars.

Ironically, even those that claimed that pictures and videos are prohibited still make ample use of them. This is because there are certain things in life one need the use of these things. Hence it is not the pictures or videos which is prohibited but the usage.

\section{The view that 2-d images are permissible in Islam}
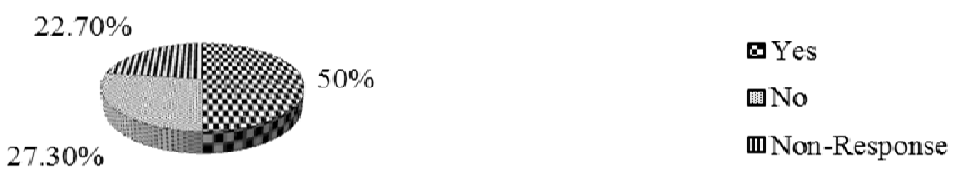

Figure 2: Scholars' views the permissibility of two-dimensional (2-d) images in Islam.

4.8 The hanging of pictures on wall is also prohibited

The issue of the prohibition affecting pictures produced through drawing and painting and photography has resulted in constructive debate among the scholars of various denominations in Islam. During the data collection period for this study, most scholars from the Sunni sect were of the position that hanging pictures in the room for decoration is also prohibited in Islam, whereas few scholars from this same sect indicated that there is nothing wrong with it provided it is not for worship. However, all the scholars from the Tijaaniyya and the Ahmadiyya sect maintained that there is nothing wrong with hanging pictures in Islam provided they are not hung in the 
place of worship or at the direction in which one is facing to observe Salaat. As for the Shi'as, they see nothing wrong with the posting of all images from statues to pictures meant for decoration.

Dr Tamin stated on 6 January 2014 in an interview that "Indeed photography is only permissible where necessity demands, and not for fun or for decorative reasons. Therefore, the answer to the question that underline the permissibility of hanging picture on the wall for the sole purpose of decoration is that; if those pictures are of animate objects, then it is better not to hang them, but if they are of inanimate objects, then you can hang them."

Dr Mohammed Awal on 11 January 2014 also said in an interview that he does not have problem with hanging pictures on the wall, but he does not do that himself. He added that he has decided to avoid it because it has then been a source of argument amongst scholars. But for him, it is not prohibited to hang pictures on the wall for decoration. The table below presents Scholars' views on the hanging of pictures on wall.

The position of the Shi'as was made clear in an interview with Sheik Dalhu on 12 January 2014, as indicated in his own words, "For decoration or for the preservation of history, picture-making is permissible." "Islam is not a backward religion; Islam is beyond what some are narrowing it to be." Allah has created the whole universe for the use of mankind, and anything in it has to be used by man, and you should also serve Allah the Almighty. All in creation is for man, and man in totality is for Allah. We need to understand that circle. This is the point of the AhlulBayt, so the idea of branding that aspect of Art as Kufur or un-Islamic is not totally accepted by the AhlulBayt." He concluded that "the idea of the prohibition of pictures, paintings, videos and statues by some extremist is a kind of reducing Islam to a very narrow point, and this is never the stance of Islam as a whole or the stance of Muslims as a whole. It is a section of Islam but not the whole Islam."

Table 3.3: Is the hanging of pictures on wall permissible in Islam?

\begin{tabular}{lcl}
\hline Permissible & Frequency & Percent \\
\hline Yes & 14 & $63.6 \%$ \\
No & 6 & $27.3 \%$ \\
Non-response & 2 & $9.1 \%$ \\
\hline Total & $\mathbf{2 2}$ & $\mathbf{1 0 0} \%$ \\
\hline
\end{tabular}

Source: Survey, January 2014

\subsection{Permissible Statues in Islam}

From the content of the hadith, all the classical scholars of the Sunni Muslims and other minority denomination agreed that the prohibition of images is mainly on sculpture and statues. Their argument was based on the series of hadith and some few verses from the Quran that seem to focus on certain statues that were worshiped by the past generations. The main religion of the people of Mecca prior to Islam was also idolatry which was facilitated by the making of statues. Certainly, the modern scholars also share the same view that the prohibition recognises sculpture as an art and statues as the products.

However, some modern scholars ruled that statues might be permitted in Islam if the intention behind the production and the usage is for the progressive development of mankind. For instance, some of the scholars interviewed agreed that statues used as teaching and learning materials, and those used as playing toys for kids were exempted from the prohibition. Some said half figured statues are permissible.

Al Qardawri (2004) quoted a hadith from Abu Dawood and al-Tirmidhi that "the Prophet (peace be on him), "Ordered that the head of the statue be broken off so that it resembles the trunk of a tree." Based on this hadith some scholars have argued that what is haram are complete figures, but if some part of them is missing without which a human being cannot survive, they are allowed; However, the true and correct interpretation of Prophet (peace be on him) asking that the head be broken off in order to make it look like a tree trunk is not that without the head life is impossible, but that the statue was then defaced and consequently viewing it would not generate feelings of respect toward it (Al Qardawi, 2004).

The literature reviewed also attested to this, and indicated further that statues for commemoration or decoration are also permitted if they are not in full figure, but rather in the form that the animals or human cannot be alive. For instance, statues that portray a figure in a portrait form or from the head to the bust (bust portraits), this to most scholars of Islam is permissible. The table below presents Scholars views on some condition that may allow for the permissibility of statues and picture.

Table 3.4: Scholars views on the conditions that may permit the need for Images.

\begin{tabular}{lcc}
\hline Views & Frequency & Percent \\
\hline Education only & 9 & $40.1 \%$ \\
Decoration only & 0 & $0.0 \%$ \\
Both & 10 & $45.5 \%$ \\
None & 3 & $13.0 \%$ \\
\hline Total & $\mathbf{2 2}$ & $\mathbf{1 0 0 . 0}$ \\
\hline
\end{tabular}

Source: Survey, January 2014 


\subsection{Effects of the Prohibition on the Muslim Child Learning Art}

The prohibitions of image-making in Islam have engulfed every Islamic community in Tamale, and is reflected in the academic programmes pursued by the Muslim children within the Municipality. Out of the ten Public Senior High Schools in the Metropolis, only three pursue visual art. None of the three schools is an Islamic school, since majority of the Islamic scholars oppose this genre of knowledge

From the field, it was discovered that all the Islamic Junior High Schools sampled for the study do not major in the visual art aspect of Basic Design and Technology (BDT). The reasons for this development according to the proprietors, head teachers and subject teachers were not only ascribed to the purported prohibition of image-making by the Hadith and Sunnah, but also other issues like inadequate skilled and competent teachers to handle the subject, and lack of pupils' interest for the art aspect of BDT.

The prohibition of images by the hadith literature remains the major reason of this development at the Junior High Schools. Several proprietors of the Islamic Junior High Schools confessed in interviews that they suggested to the head teacher, and teachers of BDT to choose areas that are not challenged by the hadith of the prohibition for the pupils to major in their learning of BDT. A teacher of BDT from Manhalia JHS confirmed in an interview that he was advised by several scholars of Islam to choose a less challenging aspect of the BDT content in the Sunnah for the pupils to major for the their BECE.

Similar reasons were ascribed the poor patronage of the visual art aspect of BDT by other teachers. Many teachers of BDT indicated that they lacked the skills and competencies of handling this aspect of the subject due to the discouragement of images-making by Islamic scholars during their early days of educational training and development. Today, these teachers cannot even deal with the core skills of BDT containing visual art content, much less, the Elective aspect? It therefore came as no surprise to be informed by the head teacher of Manhaliya JHS that no candidate for the 2013 BECE examination choose the visual arts programme for their secondary school elective.

From the survey, the enrolment at both the second cycle and tertiary institutions were quite discouraging. There was a small percentage of Muslim students in all the visual art class of all the three secondary schools undertaking visual art programmes. The least said about the tertiary, the better. The industrial art department of the Tamale Polytechnic was a disappointment in the face of the Muslim students' enrolment. Peligah introduced the industrial Arts into that institution during his tenure as Rector (2006_2012) to augment the existing Commercial Arts programme and to whip up interest in the Creative Arts. $\overline{H e}$ facilitated the recruitment of Graduate Art subject specialists, and a gifted native ceramics sculptor from Tamale as a technician to beef up the staff strength. It was discovered that the sole cause of this poor enrolment was nothing but the asserted prohibition of images in Islam. Several students in the non-visual art departments confessed that they were scared away from this genre of craft and skills training as a result of the strict condemnation of image-making in Islam.

Table 3.4: The low Enrolment Muslim Students' in three S.H.S and a Polytechnic in Art Programme.

\begin{tabular}{lcc}
\hline S. H. S / Polytechnic & No. of Students in a Class & Total No. of Muslims \\
\hline Tamale Senior High & 50 & 20 \\
Kalpohin Senior High & 48 & 18 \\
Vitting Senior High & 50 & 19 \\
Tamale Polytechnic & 34 & 14 \\
\hline
\end{tabular}

\section{Source: Survey, January 2014}

Until 2004, there were two visual art classes in Kalpohin Senior High School; these were picture-making and leather works classes. Due to the constant decreasing numbers of enrolment in the picture-making class, the school administration was compelled to close-down the picture-making class and then replace it with business since that was the demand of parents and their wards. The major factor discovered to be affecting the enrolment of the picture-making class was attributed to the emphasis laid on the prohibition of image-making by contemporary Islamic theologians.

Some institutions out of the study area are also said to have suffered the same problem in the name of the prohibition of images. This situation was witnessed by the lead researcher at the school of creative art in the University of Education, Winneba. In September 2014, a visiting Islamic theologian gave a sermon at the "Simpa Campus" mini mosque, spelled out the asserted prohibition of images in Islam; most students of arts were terrified by what he said about the punishment of the image-maker on the Day of recompense. A level-200 student at the graphic department lost control of his fear and, confounded, tried seeking the opinion of the theologian as he was already at the middle of the graphic design programme. The theologian advised the student to abandon the programme since, to him; it is against the teachings of Islam. The implications and effect of such advice by "Islamic scholars", on the future of a naïve and ignorant Art students, and the Muslim society as a whole can perhaps only be imagined, rather than quantified.

In another instance, a level-300 student of textiles and jewellery at the Art Education department at UEW also said he diverted from the picture-making class to the textile class, during his secondary education, due to the 
fear of the punishment spelled out by the Hadith literature, as stressed by some Islamic scholars. He added that some of his friends at that time diverted completely to other programmes far from the visual arts. Today, many potential painters and sculptors find themselves in the textile, jewellery, leather and even other areas not relating to art all in the name of avoiding image-making. Similarly, the only other muslim student in the Art class during co-author's undergraduate (B.A.Art) study at the Kwame Nkrumah University of Science and Technology in 1979-1980 academic year, also changed course into Architecture, when he did not get his preferred Textiles option at level 200. Happily, he became a successful Architect and a member of the team that worked on the National Central mosque sponsored by Turkish NGOs in Accra in the last five or six years. (2015-2019) still ongoing. Not surprisingly, the history of Islamic art shows a strong inclination towards religious Architecture and calligraphy with the image-making coming later during the expansions and influences from other cultures.

\subsection{The attitude of Muslim students studying art on the Image-Making aspect of Art}

The mixture of fear and doubts has characterized the hearts of many Muslim students who study Visual Art in Schools in the Tamale Metropolis. This uncertainty of the students is as a result of the impulsive reaction of Islamic scholars towards the prohibition of image-making in Islam. This hard-line preaching against imagemaking, is common among the majority Sunni scholars within the Metropolis, has discouraged most gifted children from developing their creative gifts and talents into practical realities. At the grassroots, children are discouraged from developing interest in modelling and drawing the human figure or that of any living creature; this in turn kills their natural interest and impedes their practical artistic development.

In an enquiry based on the students' attitude in learning image-making, Mr Abdul Razak, a sculpture teacher at the Tamale S.H.S on 13 January 2014, responded in an interview stating that some Muslim students in the Art class reject image-making practical class work and projects. He added that the main area for the rejection of the student was mainly the practical task involving drawing and painting, carving, modelling and casting of animate objects.

Sheik Ilyass, an Islamic teacher and a Sufi, on 23 December, 2013, stated in an interview that, "The Quran and Hadith had really condemned the making and the usage of statues (Timsal) because they underline the bases of idolatry, but for pictures, I don't think there is something wrong with pictures since they are made for commemoration." He commented that students of Art should always base their learning and work on a good intention and should be selective based on the teaching of Islam as far as possible. He recommended that they avoid nudity in Image-Making unless in a compelling circumstance like an academic task in the case of education.

At the basic schools, generally pupils learn creative arts which is the bases of Visual art genre at the senior levels of schooling. Majority of the Islamic basic schools in Tamale do not encourage the teaching of this subject. This has nipped the Muslim child's interest from the study of visual art in the bud, since the artistic skill of the child was not well developed at the early development.

During the data collection it was realized that majority of the J.H.S pupils interviewed indicated their lackof-interest in this genre since it is said to be against the religion of Islam. They however, expressed positive sentiments for photography and videos since they did not know that these were also in many cases, part of the supposed prohibited categories. To most of the pupils, they were told drawing, painting, modelling and carving of animate figures were the most prohibited aspects of image-making.

\section{Conclusion}

The underlying prohibition of image-making, both in the 2 and 3-Dimensional forms, has negatively affected the development of the Arts and Culture of the Muslim Ummah in Tamale and beyond, and has consequently affected the Artistic development and holistic education of the Muslim child.

To those who believe the prohibition involve all images, how do we have to contend with the realities of images found in our everyday life which we carry into our places of worship? Can we say we are all guilty of violating these prohibitions, since Pictures are found on our currencies both coins and notes, our identity cards, traveling passports, driving lances health insurance and even security and education all depends on pictures today. Quite obviously, we Muslims cannot avoid the use of photographs and these images in our day-to-day lives, and no Islamic or Muslim-dominated country, in the world has forbidden or banned their production or usage. As late as July, 2019, the co-author put out an updated version of his notes on the subject titled REFLECTIONS ON ART IN ISLAM in several parts across many "Whatsapp Platforms" of muslim groups, in answer to a question from a concerned Muslim: "Can a Muslim decorate his room with pictures and the like?" (Prof, Peligah; +233 546038645). Simply put, the problem is not going away and needs to be properly addressed.

\section{Recommendation}

\section{The authors recommend that:}

- The Islamic Education Unit of the Ghana Education Service, in Collaboration with the Curriculum 
Research and Development Division, [CRDD] should introduce Islamic Art, in its broader global form, into the visual art curriculum from the Basic level to the Tertiary, in schools and tertiary education Institutions, especially, in the study area and other areas with similar demographics. This will help correct the negative assumptions and misconceptions of most Muslim folks about the study or practice of visual art.

- The practical applications of the knowledge, skills and competencies in various aspects of the economy should be highlighted, beyond pure aesthetic values, so that parents, students and educators in Muslim dominated communities can appreciate the depth and scope of their potential loss if the subject is not studied or taught to their children.

- Proprietors at the Islamic schools, which are mainly privately managed, should be encouraged and tasked to allow the teaching and learning of the art of image-making in their schools.

- Students should be encouraged through special programmes, workshops and exhibitions to concentrate in their learning and practicing of the art since their primary aim is to learn and practice it for the total benefit of the society.

- Advanced Students should also educate and redirect the youth and other people's attention to the positive application of images as part of the essential aspect of life in every society in Education, Science and technology, History, business, Communication, Politics and more areas.

- Islamic Religious authorities in Ghana should take up these issues for discussions and effective decision-making re-orientation of Islamic theological training curricular in the Muslim world where preachers are often trained outside the country. The changes in the realities of the Muslim world need to be reflected in the training curricular of such preachers to appreciate and distinguish the fine lines between image-making for education, scientific and technological development and the practical utilitarian requirements of life, as against those images made for worship, veneration, pornography or other anti-social purposes.

\section{Reference}

Al-Qardawi, Y (2004) 'The Lawful and the Prohibited in Islam'. Islamicstudie.Info Available at: http://www.islamicstudies.info/literature/halal-haram/htm (Accessed:12/01/2014)

Ayuba, I. A (2011), Intra-Religious Conflicts Among Muslim Ummah (Community) in Tamale from the 1960s to 2011, M.Phil. Dissertation: College of Art and Social Sciences, KNUST

Babbie, E. (2007). The practice of social research: instructor's edition. $11^{\text {th }}$ edn. Belmot, U.S.A: Thomson Learning Inc.

Clarke, R.J. (2005), Research Models and Methodologies, HDR Seminar Series, Faculty of Commence, Spring Session.

Daftary, F. (2012), Historical Dictionary of the Ismailis: Historical Dictionary of People and Cultures; 4501 Forbes Boulevard, Suite 200, Lanham, Maryland 20706, Estover Road, Plymouth PL6 7py, United Kingdom: Jon Woronoff, Seris Editor; the Scarecrow Press, Inc.

Ibn-Baaz, A. A. I. A (1997), 'The Beneficial Response Concerning the Islamic Ruling of Pictures/Images', Presidency of Nationalistic of Islamic research \& Afta. Available at: http://www.muslimconverts.com (Accessed: May 10, 2014)

Khan, M.M. (1997), Sahih Al-Bukhari Vol.7. Medina Al-Munawwara Saudi Arabia, Islamic University.

Maulana, M. A. (2002),The Holy Qur'an: Arabic Text with English Translation and Commentary, New Edn. Ohio, USA: Ahmadiyya Anjuman Isha' at Islam Lahore Inc.

Peligah, Y.S. (2003). The Quran, art and traditions among Muslim peoples in Ghana: (Researching sources and implications on artistic expression and art education)

Rubin J. A. (2005), Child Art Therapy, New Jersey: John Wiley \& Sons, Inc., Hoboken

Usmani, M.T. (2010) 'The Legal Status of Pictures and Photography: Commentary on a Hadith from Sahih Muslim' (Z. Rahman, Trans.) IlmGate: A Digital Archive of Islamic Knowledge. Available at: http://www.ilmgate.org (Accessed: 09/01/2014)

Yin, R. K. (2009). Case study research: Design and methods. 4th Edn. Thousand Oaks, CA: Sage.

\section{Interviewee and Date(s) Rank/Position/Organisation}

Abdul-Mumin Dalhu (12/01/14) Shi'a Leader and Chief of Zongo -Tamale,

Abdul-Razak Tahir (07/03/14), an International Islamic Scholar and former ambassador of Ghana to Saudi Arabia; and a Tijaniyya scholar.

Al- Hussein Zakari (06/01/14) Director of CODEYAC, Member, Inter-Religious dialogue and Tijaniyyah scholar

Iliyasu Umar Imam (23/12/13) an Imam at the Kamina Barracks, Tamale and a Teacher at the Tamale S.H.S Imam Rashid Hussein (06/03/14) Kuthubi Zaman, a Tijaniyya Scholar and an Imam of the Salawatiyyah Islamic 
Community.

Mohammed Awal Isah (11/01/14) Sunni Scholar and a Tutor at the Ambariyyah Islamic institute Sualiu Aswad Bawa (19/10/13) Ahlus Sunnah Scholar, Imam, teacher of Nuriyyah

\section{ACKNOWLEDGEMENTS}

Prof. Alhaji Peligah as one of the early Muslim Art students in Art at the Kwame Nkrumah University of Science and Technology, in Kumasi, had similar experiences to the primary researcher here and also did extensive personal research on the subject subsequently. His student Ms Amina Gombilla conducted her Master of Art Education on "The Influence of Islam on Art Education (A Case Study of selected Muslim Communities in Tamale) in 1996, at the Kwame Nkrumah University of Science and Technology and Technology.

He also supervised an American International exchange student, from the University of Richmond, John Drew Giblin, in the same University who wrote on "The Colours of Tamale: A study of Contemporary Muslim Artists in Northern Ghana in 2001

In addition, he presented papers at International Conferences relating to the subject namely:

1. Spirituality in Ghanaian Art Education: The influence of Islam and indigenous Religious concepts on classroom practices. ( $4^{\text {th }}$ NCA conference Panel on Spirituality and the Practice of Art Education in Africa and the Diaspora); moderated by Prof. Mariama Ross, of University of Wisconsin USA. (Teachers Hall, Accra, Ghana $20^{\text {th }}$ July 2002.

2. The Quran, Art and Traditions among Ghanaian Muslims: (Researching Sources and implications on Artistic Expression and Art Education) At the $31^{\text {st }}$ International Society for Education Through Art (InSEA) World Congress, New York August. 2002. Theme: International Conversations through Art: (Re-visioning Traditions).

3. Islam, Art and Art Education in Ghana; Impressions, Misconceptions and Realities. USA Lecture tour. February-March, 2003 